\section{'Thomcord' Grape}

\section{David W. Ramming ${ }^{1}$}

Crop Diseases, Pests and Genetics Research Unit, Agricultural Research Service, U. S. Department of Agriculture, 9611 South Riverbend Avenue, Parlier, CA 93648

Additional index words. cultivar, fruit breeding, Vitis vinifera, Vitis labrusca, hybrid, table grape

'Thomcord' (Vitis vinifera L. $\times V$. labrusca L.) is a midseason, blue-black seedless table grape (Fig. 1) that is suitable for farmers' markets and shipping to domestic markets. It has the aromatic flavor reminiscent of 'Concord' with firmer flesh and skin that adheres to the flesh. It is more suitable to the hot, dry growing conditions found in the San Joaquin Valley than 'Concord'. 'Thomcord' was released to provide a 'Concord'-flavored, seedless grape adapted to the growing conditions of the San Joaquin Valley of California.

\section{Origin}

'Thomcord' originated from the cross 'Thompson Seedless' $\times$ 'Concord' made in 1983 by D.W. Ramming and R. Tarailo, San Joaquin Valley Agricultural Sciences Center, Parlier, CA. Embryos were recovered and plants produced from the seedless maternal parent 'Thompson Seedless' using embryo rescue procedures (Emershad and Ramming,

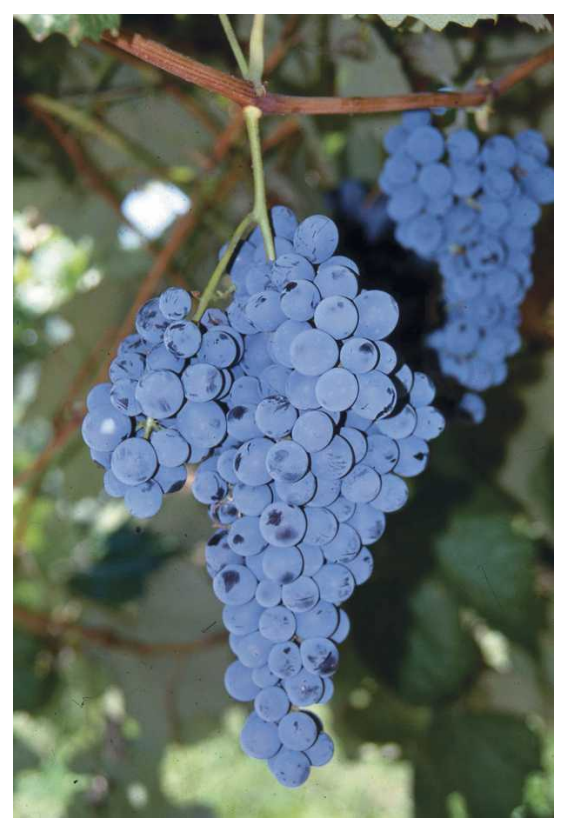

Fig. 1. Fruit of 'Thomcord' grape.

Received for publication 16 Nov. 2007. Accepted for publication 7 Feb. 2008.

${ }^{1}$ To whom reprint requests should be addressed; e-mail david.ramming@ars.usda.gov
1984; Emershad et al., 1989). The cross was originally made to demonstrate that plants produced from embryo culture were from fertilized eggs (zygotic) and not from maternal tissue (somatic). 'Thompson Seedless' fruit is white in color and neutral in flavor, whereas the paternal parent, 'Concord', has blue-colored fruit with a strong labrusca flavor. Hybrids would segregate for fruit color and flavor. From the 1231 emasculations made, 130 ovules were produced resulting in 40 embryos and three seedlings planted in the field. The original seedling vine was planted in 1984 in cooperation with California State University, Fresno, and selected in 1986 by D.W. Ramming and R. Tarailo and tested as A29-67. 'Thomcord' was tested in the San Joaquin Valley of California and publically released without restriction 11 Sept. 2003. Trials outside California have just begun. Fresno, CA, in 2001.

${ }^{2}$ Average cluster count and yield per vine. berry weight, length, and diameter from 300 berries. weight, length, and diameter from 50 berries. significant difference test $(P<0.05)$. and Venus at Fresno, CA, harvested 19 Aug. 2002. gibberellic acid or girdling treatments.

${ }^{z}$ Average cluster count and yield per vine. significant difference test $(P<0.05)$.
'Thomcord' fruit is blue-black with a whitish bloom and ripens the end of July to the middle of August in Fresno. 'Thomcord' trained to bilateral cordons and spur-pruned produced an average of $15.1 \mathrm{~kg}$ per vine compared with 'Thompson Seedless', which produced $15.1 \mathrm{~kg}$ per vine in 2001 (Table 1). The number of clusters was not thinned for 'Thomcord' because of its smaller cluster size. 'Thompson Seedless' was thinned to $\approx 35$ per vine as a normal production practice. Berry weight and diameter were larger for 'Thomcord' than 'Thompson Seedless' with similar cluster tightness. Cane-pruned vines of 'Thomcord' averaged $21.3 \mathrm{~kg}$ per vine in 2002 (Table 2). This was equal to 'Venus' and significantly greater than 'Sovereign Coronation'. Both 'Venus' and 'Sovereign Coronation' have a mild V. labrusca flavor (Danby, 1977; Moore and Brown, 1977). 'Thomcord' has yielded as much as 30 to $32 \mathrm{~kg}$ per vine in grower trials. Fruit size has not been significantly increased by girdling the vines or with applications of gibberellic acid applied at berry set (data not shown). In 2001, 'Thomcord' berry weight averaged 2.72 to $3.38 \mathrm{~g}$ and was as heavy as 'Venus' (Table 3). 'Thomcord' berries were heavier than 'Sovereign Coronation' and significantly heavier than 'Thompson Seedless'. In 2002, 'Thomcord' averaged $2.85 \mathrm{~g}$, which was less than 'Venus' but significantly more than 'Sovereign Coronation' (Table 2).

Table 1. Comparison of yield, cluster, and berry characteristics of Thomcord with Thompson Seedless at

\begin{tabular}{lccccccccc}
\hline & $\begin{array}{c}\text { Harvest } \\
\text { date }\end{array}$ & $\begin{array}{c}\text { Clusters at } \\
\text { harvest }^{\mathrm{z}}\end{array}$ & $\begin{array}{c}\text { Total } \\
\text { yield }^{\mathrm{z}} \\
(\mathrm{kg})\end{array}$ & $\begin{array}{c}\text { Cluster } \\
\text { wt. } \\
(\mathrm{g})\end{array}$ & $\begin{array}{c}\text { Berry } \\
\text { wt. } \\
(\mathrm{g})\end{array}$ & $\begin{array}{c}\text { Berry } \\
\text { length } \\
(\mathrm{mm})\end{array}$ & $\begin{array}{c}\text { Berry } \\
\text { diam. } \\
(\mathrm{mm})\end{array}$ & $\begin{array}{c}\text { Cluster } \\
\text { tightness }^{\mathrm{y}}\end{array}$ & ${ }^{{ }^{\circ} \text { Brix }}$ \\
\hline $\begin{array}{l}\text { Thomcord }^{\mathrm{x}} \\
\text { Thompson }^{\text {Seedless }}{ }^{\mathrm{w}}\end{array}$ & 20 July & 60 & $15.1 \mathrm{a}^{\mathrm{v}}$ & $259 \mathrm{~b}$ & $3.38 \mathrm{a}$ & $18.3 \mathrm{a}$ & $16.7 \mathrm{a}$ & $5.1 \mathrm{a}$ & $21.1 \mathrm{~b}$ \\
\hline
\end{tabular}

${ }^{y}$ Rating scale for cluster tightness: $1=$ very loose, $3=$ loose, $5=$ best, $7=$ tight, $9=$ very tight

${ }^{x}$ Thomcord planted 1997, spur-pruned, bilateral cordon-trained, received various gibberellic acid (GA) treatments that had no significant effect. Data from 32 vines, each vine treated as a replication. Average

wThompson Seedless planted 1996, cane-pruned, head-trained, received $2 \times 15$ ppm bloom GA $+2 \times 30$ ppm size GA + girdle. Thinned to 35 clusters per vine shortly after berry set. Data from five vines. Berry

${ }^{v}$ Means followed by a different letter are significantly different according to Tukey-Kramer honestly

Table 2. Comparison of yield, cluster, and berry characteristics of Thomcord with Sovereign Coronation

\begin{tabular}{|c|c|c|c|c|c|c|c|c|}
\hline Cultivar & $\begin{array}{l}\text { Clusters } \\
\text { at harvest }\end{array}$ & $\begin{array}{c}\begin{array}{c}\text { Yield } \\
\text { total }^{2} \\
(\mathrm{~kg})\end{array}\end{array}$ & $\begin{array}{c}\text { Cluster } \\
\text { wt. }^{\mathrm{y}} \\
\text { (g) }\end{array}$ & $\begin{array}{c}\text { Cluster } \\
\text { tightness }\end{array}$ & $\begin{array}{c}\text { Berry }^{w} \\
\text { wt. } \\
\text { (g) }\end{array}$ & $\begin{array}{l}\text { Berry }^{w} \\
\text { length } \\
(\mathrm{mm})\end{array}$ & $\begin{array}{l}\text { Berry } \\
\text { diam. } \\
(\mathrm{mm})\end{array}$ & ${ }^{\circ}$ Brix \\
\hline $\begin{array}{l}\text { Thomcord } \\
\text { Sovereign }\end{array}$ & $42 b^{v}$ & $21.3 \mathrm{a}$ & $534 \mathrm{a}$ & $5.3 \mathrm{a}$ & $2.85 \mathrm{a}$ & $18.2 \mathrm{a}$ & $17.2 \mathrm{a}$ & $21.3 \mathrm{~b}$ \\
\hline Coronation & $53 \mathrm{~b}$ & $11.6 \mathrm{~b}$ & $219 \mathrm{a}$ & $5.8 \mathrm{a}$ & $2.51 \mathrm{~b}$ & $19.1 \mathrm{a}$ & $16.2 \mathrm{a}$ & $18.6 \mathrm{c}$ \\
\hline Venus & $84 \mathrm{a}$ & $24.2 \mathrm{a}$ & $287 \mathrm{a}$ & $4.4 \mathrm{a}$ & $3.30 \mathrm{a}$ & $19.0 \mathrm{a}$ & $17.8 \mathrm{a}$ & $22.5 \mathrm{a}$ \\
\hline
\end{tabular}

Plants pruned to four to six canes averaging 20 nodes long. Two vines per cultivar, 6 years old. No

${ }^{y}$ Calculated average weight based on clusters and yield at harvest

${ }^{\times}$Rating scale for cluster tightness: $1=$ very loose, $3=$ loose, $5=$ best, $7=$ tight, $9=$ very tight.

"Berry means based on average of 50 berry sample per vine replication.

vMeans followed by a different letter are significantly different according to Tukey-Kramer honestly 
Table 3. Comparison of berry weight, aborted seed number, and weight of Thomcord with other grape cultivars at Fresno, CA, harvested 30 July 2001.

\begin{tabular}{|c|c|c|c|c|c|c|}
\hline Cultivar & Location $^{z} /$ treatment & $\begin{array}{c}\text { Berry } \\
\text { wt. (g) }\end{array}$ & $\mathrm{n}^{\mathrm{y}}$ & $\begin{array}{c}\text { No. aborted } \\
\text { seeds } \\
\text { per berry }\end{array}$ & $\mathrm{n}^{\mathrm{x}}$ & $\begin{array}{c}\text { Aborted } \\
\text { seed } \\
\text { wt. }^{\mathrm{w}}(\mathrm{mg})\end{array}$ \\
\hline Thomcord & $\begin{array}{l}\text { CSUF/Spur-pruned, } \\
\text { mix of } G^{v} \text { treatments }\end{array}$ & $3.38 \mathrm{a}^{\mathrm{u}}$ & 6 & $2.3 \mathrm{a}$ & 21 & $22.3 \mathrm{a}$ \\
\hline Thomcord & A30/Cane-pruned, $\mathrm{NT}^{\mathrm{t}}$ & $3.34 \mathrm{ab}$ & 2 & - & - & - \\
\hline Thomcord & B102/Cane-pruned, NT & $3.31 \mathrm{ab}$ & 2 & $2.0 \mathrm{a}$ & 3 & $16.9 \mathrm{ab}$ \\
\hline Thomcord & B103/Cane-pruned, NT & $2.72 \mathrm{bc}$ & 2 & - & - & - \\
\hline $\begin{array}{l}\text { Sovereign } \\
\text { Coronation }\end{array}$ & A27/Cane-pruned, NT & $2.35 \mathrm{c}$ & 2 & $1.8 \mathrm{a}$ & 3 & $21.1 \mathrm{a}$ \\
\hline Venus & B103/Cane-pruned, NT & $3.09 \mathrm{ab}$ & 2 & $2.1 \mathrm{a}$ & 3 & $11.4 \mathrm{~b}$ \\
\hline Thompson Seedless & B7/Cane-pruned, NT & $1.64 \mathrm{~d}$ & 4 & $0.6 \mathrm{~b}$ & 3 & $3.8 \mathrm{c}$ \\
\hline
\end{tabular}

${ }^{2}$ Location: CSUF, California State University, Fresno; letters represent field block location and number represents field row location.

$\mathrm{y}_{\mathrm{n}}=50$ berry sample per replication.

${ }^{\mathrm{x}} \mathrm{n}=10$ largest berries from 50 berry sample per replication used for seed trace analysis to determine maximum aborted seed size.

${ }^{\mathrm{w}}$ Aborted seed wt. $=$ mean fresh weight.

${ }^{\mathrm{v}} \mathrm{GA}=$ gibberellic acid treatments. There was no significant difference between various GA treatments so data were combined.

"Means followed by a different letter are significantly different according to Tukey-Kramer honestly significant difference test $(P<0.05)$.

${ }^{\mathrm{t}} \mathrm{NT}=$ no gibberellic acid treatments.

Table 4. Comparison of cluster, berry characteristics, and aborted seed number and weight of Thomcord with other Concord-flavored grape cultivars at Fresno, CA, harvested 6 Aug. $2002 .{ }^{2}$

\begin{tabular}{|c|c|c|c|c|c|c|c|}
\hline Cultivar & $\begin{array}{l}\text { Cluster } \\
\text { length } \\
(\mathrm{cm})\end{array}$ & $\begin{array}{l}\text { Cluster } \\
\text { width } \\
(\mathrm{cm})\end{array}$ & $\begin{array}{l}\text { Peduncle } \\
\text { length } \\
\text { (cm) }\end{array}$ & $\begin{array}{l}\text { Berry } \\
\text { wt. } \\
\text { (g) }\end{array}$ & ${ }^{\circ}$ Brix & $\begin{array}{c}\text { No. } \\
\text { aborted seeds } \\
\text { per berry }\end{array}$ & $\begin{array}{l}\text { Aborted } \\
\text { seed wt. }{ }^{y} \\
(\mathrm{mg})\end{array}$ \\
\hline Thomcord & $10.8 \mathrm{a}^{\mathrm{x}}$ & $8.4 \mathrm{a}$ & $3.3 \mathrm{a}$ & $3.28 \mathrm{a}$ & $19.3 \mathrm{c}$ & $4.1 \mathrm{a}$ & $14 \mathrm{c}$ \\
\hline Saturn & $7.0 \mathrm{ab}$ & $5.2 \mathrm{~b}$ & $2.6 \mathrm{ab}$ & $2.71 \mathrm{ab}$ & $22.8 \mathrm{~b}$ & $3.2 \mathrm{~b}$ & $22 \mathrm{~b}$ \\
\hline \multicolumn{8}{|l|}{ Sovereign } \\
\hline Coronation & $7.6 \mathrm{ab}$ & $4.6 \mathrm{~b}$ & $2.5 \mathrm{ab}$ & $2.49 \mathrm{ab}$ & $16.9 \mathrm{c}$ & $2.9 \mathrm{~b}$ & $9 \mathrm{c}$ \\
\hline Sovereign Rose & $6.8 \mathrm{~b}$ & $4.1 \mathrm{~b}$ & $1.6 \mathrm{~b}$ & $1.55 \mathrm{~b}$ & $30.2 \mathrm{a}$ & $1.9 \mathrm{c}$ & $44 \mathrm{a}$ \\
\hline
\end{tabular}

${ }^{z} n=3$ replications of three clusters for cluster length, width, and peduncle length; 50 berry samples for weight; 20 berries for ${ }^{\circ}$ Brix; and 10 largest berries to determine maximum aborted seed weight.

${ }^{\mathrm{y}}$ Aborted seed wt. $=$ mean fresh weight.

${ }^{\mathrm{x}}$ Means followed by a different letter are significantly different according to Tukey-Kramer honestly significant difference test $(P<0.05)$.

Table 5. Powdery mildew ratings in 'no fungicide spray' plot of Thomcord compared with other cultivars.

\begin{tabular}{llllllllll}
\hline & \multicolumn{3}{c}{ Summer evaluation $^{\mathrm{y}}$} & & \multicolumn{4}{c}{ Fall evaluation $^{\mathrm{x}}$} \\
\cline { 2 - 4 } \cline { 7 - 9 } Cultivar & Leaf & Stem & Rachis & Berry & & Leaf & Stem & Rachis & Berry \\
\hline Ruby Seedless & $4.0 \mathrm{~b}^{\mathrm{w}}$ & $3.0 \mathrm{c}$ & $4.0 \mathrm{c}$ & $4.0 \mathrm{~b}$ & & $4.0 \mathrm{c}$ & $3.7 \mathrm{~b}$ & $4.0 \mathrm{~b}$ & $3.5 \mathrm{a}$ \\
Thomcord & $3.3 \mathrm{ab}$ & $2.3 \mathrm{abc}$ & $3.3 \mathrm{bc}$ & $1.3 \mathrm{a}$ & & $3.7 \mathrm{bc}$ & $1.7 \mathrm{a}$ & $3.0 \mathrm{ab}$ & $1.0 \mathrm{a}$ \\
Venus & $2.0 \mathrm{ab}$ & $2.67 \mathrm{bc}$ & $2.3 \mathrm{ab}$ & $1.0 \mathrm{a}$ & & $2.7 \mathrm{abc}$ & $2.3 \mathrm{ab}$ & $4.0 \mathrm{~b}$ & - \\
Mars & $2.3 \mathrm{ab}$ & $1.3 \mathrm{ab}$ & $1.3 \mathrm{a}$ & $1.3 \mathrm{a}$ & & $1.7 \mathrm{ab}$ & $1.6 \mathrm{a}$ & $2.3 \mathrm{ab}$ & $1.5 \mathrm{a}$ \\
Niabell & $1.6 \mathrm{ab}$ & $1.0 \mathrm{a}$ & $1.0 \mathrm{a}$ & $1.0 \mathrm{a}$ & & $1.7 \mathrm{ab}$ & $1.3 \mathrm{a}$ & $2.0 \mathrm{ab}$ & $1.0 \mathrm{a}$ \\
Cayuga White & $1.0 \mathrm{a}$ & $1.0 \mathrm{a}$ & $1.0 \mathrm{a}$ & $1.0 \mathrm{a}$ & & $1.0 \mathrm{a}$ & $1.0 \mathrm{a}$ & $1.0 \mathrm{a}$ & $1.0 \mathrm{a}$ \\
\hline
\end{tabular}

${ }^{2}$ Ratings based on visual observation $(1=$ no infection; $2=$ very few small colonies less than $25 \%$ infection; $3=20 \%$ to $50 \%$ infection; $4=$ greater than $75 \%$ infection). Planted in 1996 and no fungicides applied.

${ }^{y}$ Evaluated 25 June 1998, 10 Aug. 1999, 18 July 2000.

${ }^{x}$ Evaluated Oct. 1998, 2000, 2002.

"Means followed by a different letter are significantly different according to Tukey-Kramer honestly significant difference test $(P<0.05)$.

'Thomcord' clusters average between 259 and $534 \mathrm{~g}(0.6$ to $1.2 \mathrm{lb})$ and are conical in shape with a small wing and are medium to slightly loose in tightness. 'Thomcord' has a pleasing 'Concord' flavor, although it is not as strongly flavored as 'Concord'. The aborted seed is small in size but can become sclerified and noticeable in the medium-soft flesh in some years. In 2001, the aborted seed of 'Thomcord' averaged 16.9 and $22.3 \mathrm{mg}$, which was similar to 'Sovereign Coronation' (Table 3). The aborted seed of 'Venus' was significantly less than 'Thomcord' from one location but not the other. 'Thompson Seedless' aborted seeds were significantly smaller than all cultivars tested. In 2002, 'Thomcord' aborted seeds averaged $14 \mathrm{mg}$ and were not significantly different from 'Sovereign Coronation', but were significantly smaller than 'Saturn' or 'Sovereign Rose' (Table 4). The skin is medium in thickness, not as tough as 'Concord', and adheres to the flesh. 'Thomcord' is better adapted to the hot, dry climatic conditions of the San Joaquin Valley of California than 'Concord' and other 'Concord' seedless types. Adaptability was derived from 'Thompson Seedless'. 'Thomcord' is not resistant to powdery mildew. 'Thomcord' is less susceptible than 'Ruby Seedless' ( $V$. vinifera) but more susceptible than 'Mars', 'Venus', 'Niabell', and 'Cayuga White' when comparing powdery mildew infections on leaves, stems, rachis, and berries (Table 5). The fruit has been well received in farmers' markets and could compete with 'Concord' and 'Niabell' in eastern markets.

Vegetative description. The young shoot is fully open with very dense prostrate hairs on the tip. The prostrate hairs on the shoot tip have medium anthocyanin coloration. The upper surface of the young leaf blade is dark copper red and has very dense prostrate hairs between the veins on the lower surface of the leaf. The internode of the young shoot is green with red striped coloration on its dorsal side and completely green on the ventral side. The shoots have three or more consecutive tendrils. The mature leaf has three lobes and the upper lateral sinuses are medium in depth and open. The petiole sinus is wide open. The teeth on the edge of the blade are medium in size, small in length/width ratio, and both sides of the teeth are convex. There are dense prostrate hairs between the veins on the lower surface of the mature leaf. The petiole is slightly shorter than the main vein.

\section{Availability}

'Thomcord' was indexed by Foundation Plant Services (FPS), University of California, Davis, CA, and found free of known viruses. Certified virus-free propagation material is available from FPS. Genetic material of this release has been deposited in the National Plant Germplasm System where it is available for research purposes, including development and commercialization of new cultivars. It is requested that appropriate recognition be made if this germplasm contributes to the development of a new breeding line or cultivar. The Agricultural Research Service has no plants of 'Thomcord' available for distribution. Limited quantities of cuttings may be obtained by writing to David W. Ramming, USDA, Agricultural Research Service, Crop Diseases, Pests and Genetics Research Unit, 9611 South Riverbend Avenue, Parlier, CA 93648.

\section{Literature Cited}

Denby, L.G. 1977. 'Sovereign Coronation' grape. HortScience 12:512.

Emershad, R.L. and D.W. Ramming. 1984. Inovulo embryo culture of Vitis vinifera L. cv. 'Thompson Seedless'. Amer. J. Bot. 71:873877.

Emershad, R.L., D.W. Ramming, and M.D. Serpe. 1989. In-ovulo embryo development and plant formation from stenospermic genotypes of Vitis vinifera. Amer. J. Bot. 76:397-402.

Moore, J.N. and E. Brown. 1977. 'Venus' grape. HortScience 12:585. 